Fifty Years of Service in Mineralogy: Dr. L. J. Spencer, C.B.E., F.R.S.

Mambers of the Mineralogical Society of Great Britain met in London on November 2 to do honour to Dr. L. J. Spencer, formerly keeper of minerals in the British Museum (Natural History). The occasion was the completion by Dr. Spencer of fifty years as editor of the Mineralogical Magazine and Journal of the Mineralogical Society, an honorary post which he has held since he took over the editorship from Sir Henry Miers in October 1900. The Mineralogical Magazine is issued quarterly and contains the Society's proceeding and papers read at its meetings. In 1920 the Society commenced publication of Mineralogical Abstracts as a separately paged part of the Magazine. The editor has contributed by far the greater number of all the abstracts published and has prepared topographical and subject indexes every three years. The next number of the Magazine will be a special one in his honour and will contrin papers by distinguished mineralogists from many parts of the world. Dr. Spencer was eighty in July.

Indian Scientific Liaison Office in London: Dr. S. Krishna, C.I.E.

THE Government of India has appointed Dr. S. Krishna, lately vice-president of the Forest Research Institute, Dehra Dun, and director of forest products research, to be Indian scientific liaison officer in the United Kingdom. Dr. Krishna, who was borm in 1896, was educated at the Forman Christian College (Lahore), Queen Mary College (London), and King's College (London). He held the professorship of chemistry, University of Punjab, during 1925-28, after which he entered Government service as biochemist at the Forest Research Institute, Dehra Dun. He was appointed C.I.E. in 1941. In 1948, he represented India at the Fifth Forestry Conference in London and in 1949 he visited Australia as leader of the Indian Science Delegation.

\section{British Museum (Natural History)}

IN the British Museum (Natural History) Mr. N. D. Riley, keeper of the Department of Entomology, has been appointed to be a deputy chief scientific officer, and Mr. A. W. Exell, principal scientific officer in the Department of Botany, to be deputy keeper in the Department. Mr. Riley entered the Entomological Section of the Department of Zoology in 1911, becoming keeper of the Department in 1932. He served in the Royal Army Service Corps during 1914-19 and was mentioned in dispatches. Mr. Riley has edited $T$ he Entomologist since 1922, and has been treasurer and later secretary of the Royal Entomological Society of London since 1939. He is a corre. sponding member of a number of foreign academies and scientific societies, and is the author of a large number of scientific papers, mainly dealing with butterflies from the systematic point of view. Mr. Exell entered the Museum in 1924, when he was placed in charge of the Polypetalæ. His main work has been on the flora of tropical Africa, and he made expeditions to the islands of the Gulf of Guinea during 1932-33 and in Angola in 1937. He was seconded to the Foreign Office during the Second World War.

\section{United Nations Food and Agriculture Organisation}

THE conference at Washington, D.C., of the sixtythree member nations of the United Nations Food and Agriculture Organisation, which began on
November 4 and is expected to continue for a week, marks the last occasion on which the Organisation will meet at Washington before its move to new headquarters in Rome, scheduled to take place early next year. In Rome two new buildings will be occupied; these are under construction by the Italian Government, and the first is expected to be ready in February and the second in October. Mr. N. E. Dodd, the director-general of the Food and Agriculture Organisation, has stated that with the disruption of activities caused by the move and owing to the fact that a large proportion of the staff (about 80 per cent of the lower-salaried staff and 40 per cent of the higher grades) will not be going to Rome, the work of the Organisation will be severely hampered during the first half of 1951 at least. The conference at Washington, unlike the previous annual sessions, is a special one, limited to the essential financial and administrative matters and other urgent questions which may arise. This new departure was decided on at the 1949 conference when, in addition to the resolution for the transfer of the headquarters to Rome, the principle of biennial, rather than annual, conference sessions was also adopted; under this system a full-scale conference is not to be held until the autumn of 1951 .

\section{Development of Crawfish Industry in Tristan da Cunha}

A PROJECT entailing the commercial development of the crawfish industry of Tristan da Cunha has been undertaken by the Colonial Development Corporation in conjunction with a South African fishery group. This will involve the operation of a fishery vessel, equipped with deep-freezing apparatus and deep cold-storage accommodation, to process and transport frozen crawfish tails to Capotown for regular shipment thence to the North American and European markets. In addition, a canning plant will be erected and operated on the Island itself. The Tristan da Cunha Development Co., which has undertaken the initial work of investigation, will now be re-organised, and additional finance to a total of $£ 130,000$ will be found by the Colonial Development Corporation, which will then have the financial control of the Company. The Company has also under. taken the responsibility of supplying both social and medical services to the islanders. Altogether this whole project may well be the deciding factor for the continuation of the settlement on the lonely island of Tristan da Cunha, where the community is in a difficult situation.

\section{Eradicating Barberry in the United States}

A RECENT bulletin of the U.S. Department of Agriculture ("Kill Barberry Bushes that Spread Stem Rust to Grains", Farmers' Bulletin No. 2014; April 1950) brings new methods to bear upon the time-honoured practice of controlling stem rust of cereals by destroying barberry. The use of the modern weed-killer 2,4-D is of particular interest; it is used at full strength to paint the stubs of European barberry canes immediately after the bushes have been cut off close to the ground. This method ensures that any other valuable plants growing in the vicinity will not suffer. Native barberries can be killed off with 2,4-D used as a foliage spray. Ammonium sulphamate is also used as a control, this substance being applied in dry form to all freshly cut surfaces, a pound being enough to kill several medium-sized bushes. Failing either of these chem- 